\title{
Objective Laws of Phenomenon of Metaphorization in Discourse
}

\author{
Aysel Safarova $^{1}$ \\ ${ }^{1}$ Azerbaijan University of Languages, Baku, Azerbaijan \\ Correspondence: Aysel Safarova, Azerbaijan University of Languages, Baku, Azerbaijan. E-mail: \\ ayse12017@mail.ru
}

Received: September 25, 2017 Accepted: November 6, 2017 Online Published: February 4, 2018

doi:10.5539/ijel.v8n3p167

URL: http://doi.org/10.5539/ijel.v8n3p167

\begin{abstract}
The article consists of an introduction, method of investigation, discussion on text and discourse and determination of metaphorezation, description of metaphors, place of metaphorization in literary and linguistic study, text and discourse relations, study of metaphorezation, of a conclusion and reference, each of which has found its scientific and empiric substantiation.

In the introduction the significance of the investigation from the view of comparative-contrastive method is noted, the study of the text theory and discourse, investigation of different linguistic elements used in the texts and discourses in different (English and Azerbaijani) languages are put forth as the aim of the investigation. In the introduction concise information on the study of discourse and text problems is given.
\end{abstract}

In the part, dealing with method of investigation it is spoken of the usage of typological comparative-contrastive-descriptive method of investigation which is determined as the method of investigation.

In the part of the article dealing with Discussion on text and Discourse and Determination of Metaphorization, different types of discourses, the role of metaphorization in these discourses and texts are touched upon. In this part discussion of theoretical concepts on metaphor and metaphorization find their reflections.

In the part, speaking of the place of Metaphorization in literary and linguistic study it is pointed out that metaphorization is mainly a literary mechanism and for this reason its manifestation in literature is considered, the theory of metaphorezation is discussed.

The subtitle, dealing with Text and Discourse Relations, Study of Metaphoriration, touches upon the determination of relations between text and discourse, their roles in speech and narrations, their mutual influence on each other, on the metaphorization and its functions, discussion on the theoretical view points of the scholars on these problems, manifestation of metaphors in literary texts and discourses. Extracts from both English and Azerbaijani literary pieces are introduced to illustrate the given theses.

In the conclusion all the above-mentioned issues are summarized in the concise from.

Keywords: conception, figurative thinking, communication, semantic, discourse, metaphorization, figure of speech

\section{Introduction}

Study of text theory and discourse, investigation of different linguistic elements used in the texts and discourses in different languages has occupied a vast range of researches among the investigators of the world. From this view comparative -contrastive method of investigation of text and discourse problems are of great significance. Metaphorization is one of the fields of lexicology and stylistics demanding careful study within the texts and discourses of different compared languages.

While the modern theories grow more and more in the text theory, the text itself is looked upon as the system of signs, and in the field of creation of texts and their cognition new scientific principles are discovered. Earlier the investigators studied more of grammatical paradigms of texts (text grammar rules) and paid less attention to discursive, symbolic and metaphoric peculiarities of literary texts. During the last years, in separately-taken research works, scientific, publicist, business text (discourse in the wider sense), their linguistic and figurativeness are determined, in this aspect wide range of thoughts are being formulated (Bakiyeva, 1992; Fyodorova, 1994).

In the American-English linguistics, the main notion, expressing different aspects of text is discourse. Discourse 
in English Connected Speech is just the narrated text. In this respect, discourse is different from the text which is taken as formal grammatical structure and cognized in this aspect. Discourse is a coherent text which is established and directed to the interlocutor by the speaker. Discourse appears as the result of interactive process in the sociocultural context.

In the modern text linguistics, textual structural rules, possessing a certain hierarchic completion and functional, discursive ties determined as to these rules are studied. Discourse, being a field of science of coherent text investigations, finds its place within philology as a whole (Grey, 2000).

\section{Method of Investigation}

It is necessary to note that in the study of the problem, which is absolutely a new field in the linguistic and literary study, usage of one method of investigation is not appropriate. That's why in the study of the problem the author of the article has chosen the usage of the Method of tenacity within the Practical Diachronic Model.

The article, dealing with two languages (English and Azerbaijani languages) belonging to different systems among the languages of the world, the usage of typological comparative-contrastive- descriptive method of investigation with the experimental illustration of the specimens of both English and Azerbaijani models of metaphorization are applied.

\section{Discussion on Text and Discourse and Determination of Metaphoization}

During the recent years the scientists highlight the possibilities of metaphors in creating characters in the discourses of different types. By the strengthening of metaphorization in business talks, speeches vivify more and more. In this sense, it is considered that business talk is just business discourse. This derives from the objective laws of development of any language. Mechanism of metaphor establishes the functions of discourse. Metaphors, among different discourses, play the role of integration (Teliya, 1968).

A member of linguists gives advantage to consider metaphor in business discourse because it is reslated to the globalization process. For ex.

The reason why we focus on political discourse is that it is the type of discourse with one of the most frequent metaphoric and metonymic representations of concepts (Musolff, 2004; Zinken \& Musolff, 2009; Hart, 2011).

The character features of characters in the literary works, in most cases are revealed in the process of relationships, during a certain work, thoughts etc. and these characters explain their world outlook, their attitudes to life, to the events taking place in the world, to the society and the human-beings by metaphoric means, by the methods, creating figurativeness.

Metaphors are one of the main means of expressing figurative thinking. Metaphorization acquiring a wider sense is a lexis-semantic phenomenon created as a result of copying the meaning of a word on the basis of similarity. As Reformitski pointed out "metaphorization is not only the product of a literary language, but it is also the product of human-thinking" (Reformatski, 1955).

In the text linguistics "discourse" is considered one of the paradoxal phenomena. In linguistics the notion of "discourse" has been explained from different approaches. Discourse, being a cultural-situative notion "is determined by the extra linguistic, pragmatic, sociocultural, psychological and by other factors in the communicative text and cognitive process become clear, "the loaded life" is characterized" (Borbotyu, 2006).

Metaphors create strong coordination in the discourse of the text. Namely, metaphors supply the coordination in discourse, carries out the function of metafunctions of the language. Metaphors act as a means in establishing the text. Concentrated metaphor at the beginning of a text carries out the revelation of the idea of the text, discusses the theme of the text, puts the attitudes between the author and readers in order. At the same time metaphors divide individually-taken discourses into parts. Figurative speeches of the participants of communication are systematicised. Thus, metaphors within the texts structuralize the discourses; play an important role in understanding and memorizing the notions.

Metaphorization in discourse acts as a means to create meaning and thought creates possibilities for the impressiveness and activeness of the texts (Makarov, 2016)

Metaphor function in the discourse as to three principles: compact principle, principle of clarity, principle which is not expressed (Makarov, 2003).

Metaphorization plays an important role in the fixation of new scientific results. A scientific text not only gives intellectual information, but also it sets up an attitude of mutual intercourse. The used metaphors bear evristic character in the scientific texts; bring forth professional units in terminology. In this respect new facts are 
discovered. The language means, which are the products of the individual creativity of the author (expressive terms, for e.g. in the science of electro technique: the wire is alive/dead: in the science of mathematics: backward operator, in the science of architecture: Khram dushi, bazis mishleniye (in Russian), aggressive balcony: in linguistics: load of meaning, in policy; love and business, political coalition, policy market etc.).

Relationship of metaphorization of figurative meaning in this process, increase of meanings of words and word combinations, expansion of the possibilities of policemy, scientific, publicist texts, including the investigation of text and discourses as to their types, some of the drawbacks show themselves.

Metaphorization is a phenomenon created in the system of signs. In this system the contents and essence of this phenomenon, its typology and linguistic-cognitive basis exist.

Metaphorization as a process is an opportunity in which new name or expression is created (Lakoff, 1980).

\section{Place of Metaphorization in Literary and Linguistic Study}

Metaphorization is a literary mechanism. Discovering the discursive models, to find out this process, to determine the instances of formulation of the new name, are the features, conditioning the urgency of the theme.

Metaphorization phenomenon in discourse is created by the richest possibilities of the language. This event is turned to a factor in the literary language. These expressions enrich both the vocabulary and literary language from the aesthetic view-point.

Just these factors, which condition the urgency of the theme, serve to discover the "secrets" deriving from different styles, especially from the literary style.

Metaphor is one of the complex enough figures of speech. This type of figure of speech is an act to cognize the world.

Metaphoric meaning appears by the way of copying the names as to similarity, by the way of relating them to the others.

Metaphor is understanding of unknown to us things, actions and qualities by the similar features of known to us things, actions and qualities.

We think it necessary to memorize a thought spoken by Afandiyev: "As the other phenomena of the language the phenomenon of metaphorization is of historical character, namely like other lexis-semantic categories of the language metaphor is also developing. This is proved by the facts of the literary style (Afandiyeva, 1980).

As to the thoughts of Ganbarov, who has written a special research work for receiving the scientific degree of philosophy doctor, metaphorization is a historical semantic process. Being linked with the history of the Azerbaijani language, as an important source it enriches the vocabulary of the language and the system of figurativeness (Ganbarov, 1987).

The process of metaphorization is realized by the way of semantic change of the word. Reformatski noted that in the process of metaphorization the meanings of the words, denoting objects or notions absolutely change (Reformatskiy, 1967 ).

These changes can be proved by the following facts expressed in a literary piece: Qışın sart külayi ağacları kökündən qopard1. Bu nəğmən ruhumdan qoparmı, bilməm, mənə ilham verən dostlar olmasa? (Vurğun)

Translation: (The severe wind of the winter swept off the trees from their roots, How could this song take off my spirits, I don't know, if there were no friends, inspiring me?)

The main factors conditioning the metophorization are both linguistic and cognitive bases (natural events etc.) and the complex study of its linguistic, cultural characterology.

In the semantic conceptual frame, the objective laws of the realization of metaphorization, including the determinations of traditional translations can be characterized as urgency of the research work. One of the main features of metaphorization is its peculiarity of forming a text and a discourse.

Metaphor is an extremely practical means. Metaphor, in all fields may act as a means of influence and explanation. In the psychotherapeutic fields in the talks between the pilots on airline, in ceremonies, in the programmed languages, in literary figure of speech, including the quant mechanism it can find its investigation.

Metaphor here is used; it always activises human actions, their activities, knowledge and understanding of their thoughts and enriches them. The fact that metaphor is used everywhere is a major factor, affirming its belonging to different discourses. Just this feature actualizes the study of metaphor from discursive aspect. For e.g., Let's consider one text: "Mugham and Ashug art are the world treasures of world music. The nature as always vivifies 
unrepeatedly, the mugham and art of ashug too are arts, notwithstanding any border, free arts taking use of their own selves. We inherit mugham to the future generations as a part of our spiritual world. Just mugham left as our heritage to the future generations being bound with deep roots, tries to teach national dignity, feeling of pride, emotional richness, endurance to suffering, sympathy to the sufferings of other peoples, the national perfection which mugham itself possesses qualities of completion".

Such text-discourses show that metaphorization remains undiscovered in revealing the necessity of approach from the angle of discourse analysis conditioning the revelation of general thoughts on the basis of examples, and essence in deeply understanding of discourse analysis remains much enough undiscovered. So, we may say that the obligatory learning of discourse analysis is also uncognised.

Functional peculiarities of Metaphorization involves the following functions: 1) meaning forming function; 2) descriptive function; 3) cognitive function; 4) pragmatic function; 5) expression forming function.

It is worth mentioning that a text is also a system of signs. Discourse in the symbolic meaning, in the sociocultural context appears as the result of interactive process.

\section{Text and Discourse Relations, Study of Metaphorization}

Discourse is a polysemantic term and in the language it is functionalized. Discourse is being studied by such science as linguistics, literature study, semiotics, sociology, philosophy, ethnology, anthropology and so on.

Discourse is also a linguistic term. This term, in the determination and explanation of Benevist sounds as high narration in the wider sense of meaning, something which is determined by the speaker and the listener (Benevist, 1974).

Highly discourse-narration being the function of dialogical speech, is a "means of communication", is an actualized unit of communication. Discourse - narration in a certain speech condition is a unit of intercourse, cognized by the speaker and possessing semantic completion.

Narration-discourse is a communicative unit, expressing a certain thought. Narration in most cases, though fits to the text, in some cases goes beyond the circle of the text, is considered as the free unit of the language system and is chosen from the sentence, possessing low level unit.

Discourse as a language unit can be expressed with the terminological unit as "narration". Approximately in the same understanding "expression", "information", "maxim", "syntagm", "speech act", "utterance" and other terminological units can be used as well. However, we think, their borders must be specified.

The theoretical backgrounds of Discourse establish language-discourse-text order. Discourse is an individual speech union. Discourse is a social speech activity. In the level of discourse productive metaphoric models are created in the text.

Cognitive investigations exit in discourse. In the Azerbaijani linguistics in this aspect investigations are being carried out. Within the frame of different spheres of communication daily, political, economical, literary and other discourses act.

Discourse - text order is like this: 1) dynamic process of speech activity; 2) it must be understood as the result of speech activity.

The fields belonging to discourse category are these: social field, linguistic field.

Discourse $=$ text + extra linguistic context.

Formally discourse of this type can be determined like this: discourse $=$ text + context (linguistic and extra linguistic).

Above-mentioned, discourse is a coherent text. Coherency is a characteric feature of the text. Coherency is understood before everything as the wholeness, possessing relatively syntactic and stylistically mutual dependence, and coherency is the result of mutual influence of logical-semantic, syntactic and stylistic types of cohesion. Coherency is one of the means, ensuring the logical-semantic wholeness of the text. Coherency conditions the wholeness of the text. Coherency plays an important role in the formulation of the discourse in the text.

Cobrina wrote that, "Dialogue is more characteristic for the dialogue discourses. Complex coherency interprets relevant features of the text, it creates grammatic, lexis, prosaic or logical-semantic and communicative wholeness of the discourse in the dialogue (Kobrina, 1985).

Moskalskaya writes that, the biggerness of the text appears closely with coherent texts in modern linguistics: 
"Tselostnost teksta, organicheskoe soedineniye ego chastey svoystvenno dialogu. Kogerentnost teksta: ne est yavlenie tolko smislovoye, ona provlastno odnovremenno v vide strukturnoy, smislovoy u kommunikativnoy; tselostni kotorie sootnositsa mejdu soboy kak forma soderjaniya u funksiia" (The wholeness of the text is organic connection of its parts peculiar to the dialogue. Coherency of the text is not a phenomenon as only semantically. It is ruling simultaneously in the form of semantic and communicative structure; wholeness of which relates to the contents and functions with each-other) (Moskalskaya, 1981).

In the text-linguistics there are specific conceptual features of coherency. More exactly, basing on these features, text is considered as a system of signs.

In modern linguistics already in the research works, general anthrocentric directions being taken as targets, "human factor" is emphasized, in the style of the language (literary, publicist style etc.), the wisdom of human-being, his/her consciousness, thinking, moral-practical activity, etc. is taken as a basis. The role of human factor in linguistics ensures the creation of new directions of communicative linguistics and cognitive semantics. Language and its system of signs as a communicative activity began to be studied as a "panorama of the world".

Some linguists determine features as a part of non-verbal metaphor: This gesture qualifies as metaphoric in that it is used to express a non-physical idea - a positive evaluation of something - in terms of a physical, spatio-temporal representation (Müller \& Cienki, 2009)

Stepanova noted that "Metaphor is a fundamental means of language, is an oppositional element of the language (Stepanova, 1985).

Metaphorized thought-character, block of metaphor include comparative, metaphoric epithets and some others. In still wider circle on the basis of vital metaphors, metanomies, sinedoches, symbols (semantic signs) comparisons and similes, oxymorons etc. linguo-culturological basis of this literary phenomenon is studied.

The evolution of individually taken troops in this process and in the literary context is watched, and their functions are analyzed. The functional aspects of metaphorization descriptive function, cognitive function, text-forming function, meaning-forming function, pragmatic function are investigated. The forms of metaphorization in discourse and its types, different styles, forms of manifestation of the phenomenon of metaphorization in the system etc. are investigated.

On the bases of discursive analyses in two languages, belonging to different languages, the following functions of metaphorization are determined:

1) The function of creating terminology.

2) Text-forming function.

3) Meaning-forming function.

Discursive analysis makes it possible to consider the creation of different types of metaphors in the communicative process. The contents and essence of the phenomenon reflected by the discourse and thinking, influence on the human behaviour by means of signs, regulated experimentally by the types of metaphor, which in its turn is observed by subjective factors. Consequently in the cognitive block, depending on the psychological, individual signs in the cognitive block metaphors become conceptualized, namely they are imagined.

"Metaphorezation in discourse is a phenomenon deriving from the semantics of the language unites. This process increases the possibilities of expressiveness of the discourse and enriches the word stock of the language and formulates metaphoric lexis in discourse" (Afandiyeva, 2017)

In the literary discourse exist specific linguistic and figurative bases of metaphorization. In the literary atmosphere, the process of metaphorization is a phenomenon, bearing discursive distinction being in close ties with the sentence and text. Different from ordinary normative sentence in such syntactic sentences, when the size is metaphorized syntactic molding becomes newer, in the mode of expression the power of the means of metaphorization increases.

In the discourse the investigation of the phenomenon of metaphorization indicates the success, achievements of conceptual theory of metaphor. Such an approach to the process of metaphorization within discourse is considered as complex-verbal-character, by this time such questions appear: "where is the system of character in discourse", where do the notions of new fields appear? In the process of the investigation these important questions are answered.

Discursive analysis of the process of metaphorization is carried out within the text. Discursive analysis of metaphorization on the materials of the Azerbaijani and English languages once more proves that creation of 
metaphors in the language system, before everything is the phenomenon of thinking and conscious. It is directly linked with the cognition of things and mutual logical links among these things by the human consciousness.

In the process of metaphorization epithets are especially chosen. Epithets are used as one of the main indicators of modality in the text. Different from sentence epithets-literary attributes belonging to the same object in the text may be distributed among the different units. For e.g., "Bu fikir bir an içində cavan oğlanı utandırıb, qıpqırmızı qızartdl. Muncuq-muncuq tər damcıları onun alnını bürüdü. Buna görə də oğlan dayandı, cib yaylığı ilə tunc rəngli əsmər üzünü sildi. O, pərtliyini gizlətməyə çalışd1, (East-West”, 2009) He experienced a momentary pang of shame that he should walk so uncouthly. The sweat burst through the skin of his forehead in tiny beads, and he paused and mopped his bronzed face with his handkerchief. (Jack London, Martin Eden; $p$. 18)

The world is a fine place and worth the fighting for. I have very much to leave it. And you have a lot of luck, he told himself, to have had such a good life (E. Hemingway).

Comparison-contrastive way is one of the types of metaphorization. The means of comparison in the text formulates figurativeness in the discursive locality. For e.g. Birdən birə ona elə gəldi ki, bu saat masanın üstündəki kitablara toxunacaq, buna görə də ürküdülmüș at kimi geri sıçradı və az qaldı royalın qabagındakı kətili aşırsın (London, 2009)

He did not know what to do with those arms and hands, and when, to his excited vision, one arm seemed liable to brush against the books on the table, he lurched away like a frightened horse, barely missing the piano stool (London, 1954).

Sometimes discourse comparison mingled together, creates the phenomenon of metaphorization. For e.g.: "Onun həssaslığ 1 daha da şiddətlənmiş, pərtliyi isə həddini aşmışdı. Buna görə də Arturun mıktubunun üstündən ona dikilən oğrun baxıșları oğlanı bir bıçaq zərbəsi kimi yaraladı (London, 1954). He was keenly sensitive, hopelessly self-conscious, and the amused glance that the other stole privily at him over the top of the letter burned into him like a dagger-thrust. (Jack London, Martin Eden; 1954).

In the discourse the epithet "oğrun baxışlar" "oğlanı bir bıçaq zərbəsi kimi" have been used in one place or: "Әvvəl o, məni açmadı, amma sonra gördüm ki, qızıl kimi adamdır” (Anar, 2003).

In this text by the participation of the conjunction "amma"- "but" discourse has been formulated.

The white mares of the moon rush along the sky

Beating their golden hoofs upon the glass Heaven;

The white mares of the moon all stand on their hind legs

Pawing at the green porcelain doors of the remote Heavens.

Amy Lowell (Night clouds)

White mares of the moon is a metaphoric expression used to denote white clouds taking the shape of mares under the moonlight.

Pawing-verb "to paw" means here "to scratch" or "to tramp with the paw".

Vermilion-means bright red colour. By this the author of the poem means the colour of the sun rising in the morning.

In the literary text the main plot of contents possesses systematization. The object which is described in the same order and complete clarity of attitude to the subjects may also be a systematic process. In one of the elements one feature of the attitude of the author to the object is interpreted but in the other unit another feature is interpreted. In some cases the author in one of the units of the text reveals his all-rounded attitude to the object. The fact that the formulation of the attutude of the author to the object and to the subject is formulized in the uncompleted form of the text, bears certain contents in the text. For e.g., An attitude of the writer expressed to an object (a board hung on the wall: Yağlı boya ilə çəkilmiş, divardan asılı lövhə onun nəzərini cəlb etdi. Böyük və qüdrətli bir dalğa sahildəki qayaya cırpllıb parçalanırdı (This is one feature of the attitude). The second feature is in the other element of discourse: Lowering storm-clouds covered the sky; and, outside the line of surf, a pilot-schooner, close hauled, heeled over till every detail of her deck was visible, was surging along against a stormy sunset sky (London, 1954). "Göyün üzünü aşağ 1 enmiş buludlar bürümüşdü, qürub edən şəfəqin günəşli şəfəqlərinə boyanmış, şahə qalxan dalğalar üzərində kiçik bir yelkənli gəmi vardı. Gəminin bir yanı elə əyilmişdi ki, bütün göyərtəsi aşkar görünürdü. Bu mənzərə çox gözəldi-gözəllik isə cavan oğlanı yenilməz bir qüvvə ilə çəkib öz ağuşuna atırdı (London, 1954)". 
This discourse can be named as "Lövhə" (landscape).

In the texts of such kind the quantity of discourse units while increasing, the information, related to the both, the time and place widen as well. Widening is achieved both factually and as to the field of information.

When the speaker (writer) in his desire to present an elaborated image does not limit its creation to a single metaphor but offers a group of them, each supplying another feature of the described phenomenon, this cluster creates a sustained (prolonged) metaphor. For example: "Mr. Dombey's cup of satisfaction was so full at this moment however, that he felt he could afford a drop or two of its contents, even to sprinkle on the dust in the by-path of his little daughter" (Dickens, "Domy and Son").

In the given example the word cup (of satisfaction) being a trite metaphor is revived by the following contributory images: fill, drop, contents, and sprinkle. It is interesting to note that the words conveying both the central image (the cup) and the contributory images are used in two senses simultaneously: direct and indirect. The second plane of utterance is maintained by the key word-satisfaction. It is this word that helps us to decipher the idea behind the sustained metaphor.

Certainly each of language units possesses an information load. Information is determined by the degree of certainty. Plurality of language signs and lawful combinations increase the degree of definiteness of the information. The thought of academician Kamal Abdullayev here justifies itself: "Information as a whole shows itself not in the sentence, but just in the unity of sentences, namely, just in the text. Just the unity of sentence, which is the main factor for the speech activity may turn to the information shelter" (Abdulla, 2016).

As to the thought of Mammadov, speaking on the three information types sent in the text during the intercourse (cognitive, language and communicative types), a text possesses certain cognitive information as a cognitive unit and sending this information to the acception of a text refers to the function of the text. Cognitive information is knowledge on the world, received as a result of psychical activity, and expressed socially by the system of signs. Language information is information, sent by language units on the world. But the cognitive information is information on the author's though expressed in the text (Mammadov, 2001).

While a text is being established, information increases; it takes a direction from meaning to the contents. Galpern indicates 3 types of information used in the text (for e.g., imaginations on painting): 1) factual; 2) conceptual; 3) covert meaning of the text.

Factual information indicated above in the text "landscape" unites information on the events, facts, processes in itself.

Conceptual events and processes in the text "landscape" express the author's attitude to their participants (He has not the vaguest information on painting).

The covert information in the text "landscape" derives from associative and connotative meanings. This meaning is carried out by modal reality. "He had seen oil paintings, it was true, in the show windows of shops, but the glass of the windows had prevented his eager eyes from approaching too near". (London).

One of the types of discourse is a "universal discourse" In the linguistic science 8 "universal discourses" are pointed out. These discourses involve the following discourses:

1) Different ways of marking the beginning and the end of text. One of the ways is the sign "Lövhə" (landscape). This word has been used both at the beginning and in the end of the text for the sake of marking, and has been able to close the text both structural-semantically and logical-semantically.

2) The ways of marking inner passages of communicative texts.

3) Temporal connections.

4) Connections of locality.

5) Logical connections.

6) Identification of the participants of the discourse.

7) Choice of different elements for focusing the attention on them.

8) Cognition of the author or his attitude in the work.

A part of these universal discourses can be easily chosen from the text.

Indication of the name of character or image by the personal pronouns from the text of "Landscape": O, (yəni cavan oğlan) öz yöndəmsiz yerişini unutdu və lövhənin lap yanına gəldi. $O$, indi rənglərin qarşısından ibarət cizma-qaraya çevrilən şeyə təaccüblə baxırdı (text in the discourse several times by the word "o" (he) and also instead of ("the young 
man") (cavan oğlan) whose name is not known, are repeated.

The writer, can create connection among the parts of the text by some other means. Instead of the name of the personage, known information about him is used. For e.g.: "cavan oğlan" (young man).

In the literary fiction some of the writers having written about winter have personified it. But to the feature of "to kiss" (öpmək) Karimli as a poet pays such an attention.

Külək qarı püskürür

Yerdən göyə qar yağır

Q1şın öpüşü kimi

Şaxta yapışır üzə (Đllər şeirindən).

(Wind sweeps up snow

It snows from the Earth to the sky

Like the kiss of the winter

Frost sticks to the face (from the poem "hands")

Here "frost" (şaxta) remains in our imagination as "warm kiss" (cold kiss).

The process of metaforization is met in the scientific linguistic and scientific popular discourses as well. (Scientific) metaphoric models are realized in communicative-cognitive locality. In the scientific discourses specific metaphoric models as a rule are formulated. In the scientific discourse metaphorzation turns to a problem. Thus, metaphors in the widest sense of word determine the specific peculiarities of scientific notions. Certainly in the revelation of the specific features of scientific notions terminology plays an important role, metaphoric units enrich the scientific speech. Metaphors as a cognitive resources act (in the wider sense) in the text. Here, metaphor shows itself as a unique understanding (cognition) mechanism. In the linguistic texts (in the wider sense in the discourse) metaphorization becomes functionalized.

In the linguistic discourses sometimes the language peculiarities of scientific texts penitrate into the literary text. It is demanded that, scientific informativity should not switch off the light of literary emotionality. Generally speaking, a number of writers know what the volume of discourse in the literary text is. For e.g.: Amma İsfəndiyar kişi evə tələsmirdi. Dəmiçixananın böyründən axan arxın üstünə körpü əvəzinə qoyulmuş dəmir borunun oyuğundan konserv qutusunda araba yağı ilə əski parçasını götürüb, qara xrom çəkmələrini yaxşı-yaxşı silib parıldadır, torpaqla və otla sürtə-sürtə əllərinin hiss-pasını yuyur, həmişə köynəyinin döş cibində gəzdirdiyi daraqla saqqalının altını, üstünü dapayıb sığallayır, qurum və kömür qoxuyan papağını çırpıb başına qoyur, gödəkçəsi çiynində, təsbehi əlində, zərif, nurani sifətinə bir az kobudtaraq, kökməzək bədəni şax tutub, ağır, yorğun addımlarla kəndin ortasına, iradənin qabağına yollanırdı (Hüseynov, 1987)

In this discourse a clear portrait is established, the clear and bright colours of this literary view is obviously seen in one look. In the vision of the portrait and in its cognition if there is nothing left for understanding, it means, that discourse has carried out its duty in the finest way.

Namely, each discourse has its volume and context, the sentences establishing the literary discourse possess their own loads and have their own weights. The words and expressions here make their social belonging of the character, the degree of intelegence or non-inteligence is obviously seen. In each discourse, there exists proper, self-belonging peculiar of stylistic devices.

In the linguistic discourses metaphpric models, mainly are set up on the following expressions: "the character of language", "the language of morality", "metaphoric basis of many characters", "object of the language", "language mechanism", "language play", "dynamic structure of a language", "language-flowing conglomerate", "language establishing activity", "Verbal communication", "Language organism", "inner form of a language", "inner form of a word" etc.

Metaphorization is productively used in the publisistic discourse.

In the publicistic discourses in the expression of the events, occurring in life discourses do not take place only in the way of enumeration of these events, but also by the way of literary, passionate way of expression, they express in the laconic form in which metaphorization plays a special role. For e.g., All the beauty of the language of radio, the expression of emotions are conveyed verbally, here the main power is the power of metaphoric figures. For e.g., Salam, istəkli dinləyicilər...isti hərarətini, hənirtisini və çaparaq gəlişini böyük ümidlə qarşılayırıq. Yazın ilıq nəfəsi, mehini ciyərdolu uduruq və insanların hamısına xoş olan bir inamla bu baharın, bu 
ilin daha sabatlı və daha çox bolluq gətirəcəyini tez-tez təkrar edirik (from the broadcast "Spring is coming").

Metaphor gives a jerk to cognitive operations, this especially shows itself in political and media discourses. As to the thought of Lakoff, metaphorization does not belong only to the literary style, but also it belongs to the political discourses as well (Lakoff, 1990).

Thus, discursive analysis helps to clarify extralinguistic factors, to place them properly in the text. Description of the situation brings clarity to the text. Certainly, for learning the process of metaphorization, the way how it is created and its importance in the language, it is necessary to carry out discoursive analysis. Such an analysis creates possibilities to clarify the reasons why in the process of communication different, colorful numberless metaphors are created. The essence of the event expressed by the discourse and thinking, influences persons conducts by the signs, regulated by metaphors, which is accompanied in its turn, by subjective factors. Consequently in the cognitive blocks, metaphors, without depending on psychological features, are conceptualized.

In discourse a number of levels of metaphorization exist: internal level, the main level and the nuclear level. In the nuclear level of the discourse productive metaphoric models (degrees of metaphors, lower, middle and upper degrees) are formulated.

\section{Conclusion}

Eventually the main focus of attention in the investigation is directed to the better understanding of metaphoric expressions, which challenges the people to creativity, motivates them to activize the usage of metaphors in their speeches for making these speeches more colourful, more interesting, also it is diredcted to the improvement of cognitive and conceptual metaphor theory.

Metaphorization is the product of human being, always having tendency to figuration. It is one of the categories of the language. As a result of Metaphorization the converted meanings of the word, its lexis environment is determined. The cases of aquisition of meanings in different forms are harmonized as to the rules of objective world, as to the character of this or that event, as to the mode of thinking. For e.g., "yalançı dünya" (A false world).

Investigation shows that the role of metaphorization appears, linked with discourse. There are a number of reasons conditioning the urgency of the theme. Learning of metaphorization phenomenon in the level of discourse and discourse units proves the necessity of consideration of the signs of informativity of the text, its cohesion, coherency, implicativeness, integracy, and signs of modality.

Individual-author metaphors in the discourse discover invariant structure, semantic psychological, ethno social-cultural, aesthetic and pragmatic factors.

The investigation of this phenomenon in the aspect of discourse has a specific role in the revelation of idea-aesthetics of the work.

Investigation shows that metaphorization as a process is of discursive character. Speech metaphors work actively in the scientific sphere.

Discursive analysis of metaphorzation once more proves that appearance of metaphors in the language system, before everything is the phenomenon of thinking; it is linked with the cognition of mutual logical ties among the objects and events.

\section{References}

Afandiyeva T. (2017). Lexis style of the Azerbaijani linguistics. Literary style. Baku: Elm.

Afandiyeva, T. (1980). Lexis Style of the Azerbaijani Language (literary Style). Baku: "Elm" publishing house.

Aliyeva, M. (2013). Mugham and Ashuq Art. "For the sake of literature", Newspaper, No. 8.

Bakiyeva, G. Kh. (1992). Linguistic bases of the analysis of the literary texts. Abstract.dis.doct.phil.Sciences. Tashkent.

Benevist, E. (1974). General Linguistics.

Borbotyu, V. G. (2006). Principles of Formation of Discourse: From Psycholinguistics to Linguosynergetics. URSS.

Fyodorova, N. B. (1994). Figurative structure of the literary texts. Abstract.dis.doct.phil.Sciences. Tashkent.

Ganbarov, A. R. (1987). Metaphors in the Modern Azerbaijani Language. Acad., Baku. 
Grey, W. (2000). Metaphor and meaning (Electronic resource). Minevra-An Internet Journal of Philosophy, 4.

Kamal, A. (2016). Theoretical Problems of the Syntax of the Azerbaijani Language. Baku.

Kobrina, M. A. (1985). Coherent Characterisitics of Dialogical Texts. Abstract. dis...cand.of phil.sciences. Pyatiqorsk.

Lakoff, G. (1980). Metaphors we live by. M., Johnson, Chicago.

Lakoff, G. (1990). Metaphors with which we live. In G. Lakoff \& M. Johnson (Eds.), Theory of Metaphors.

London, J. (1954). Martin Eden. Moscov, 1954.

Makarov, M. L. (2003). The Basis of the Theory of Discourse. ITDGK, "Gnosis".

Makarov, M. L. (2016). The Principles of the Theory of Discourse. Moscow.

Mammadov, A. (2001). System of Formal Means in the Creation of Texts. Baku, "Elm".

Moskalskaya, O. I. (1981). Grammar of the Text. Visshaya Shkola.

Müller. (2002). Body Memory, Metaphor and Movement (pp. 201-226). Amsterdam: Benjamins. Kövecses, Zoltan.

Reformatskiy, A. (1955). Introduction to linguistics.

Reformatskiy, A. A. (1967). Introduction to Linguistics. Moscow, Prosvesheniye.

Stepanova, U. S. (1985). In the Text measuring space of the Language.

Teliya, V. N. (1988). Metaphorization and its role in the creation of the language map of the world. The Role of Human Factor in the Language.

Zanina, M. A. (2012) Metaphorization in the Scientific-Popular Discourse. Journal, News of Sanct Petersburg University, 9(3). Philologgy, Oriental Study, Journalism.

Zinken, J., \& Andreas, M. (2009) A discourse-centered perspective on metaphorical meaning and understanding. İn A. Musolff \& J. Zinken (Eds.), Metaphor and Discourse (pp. 1-8). London: Palgrave, Macmillan.

\section{Copyrights}

Copyright for this article is retained by the author(s), with first publication rights granted to the journal.

This is an open-access article distributed under the terms and conditions of the Creative Commons Attribution license (http://creativecommons.org/licenses/by/4.0/). 